University of Nebraska - Lincoln

DigitalCommons@University of Nebraska - Lincoln

Nebraska Cooperative Fish \& Wildlife Research Nebraska Cooperative Fish \& Wildlife Research Unit -- Staff Publications

2012

\title{
Latitudinal Influence on Age Estimates Derived from Scales and Otoliths for Bluegills
}

Lucas K. Kowalewski

University of Nebraska-Lincoln, lkowalewski2@unl.edu

Alexis P. Maple

University of Nebraska-Lincoln

Mark A. Pegg

University of Nebraska-Lincoln, mpegg2@unl.edu

Kevin L. Pope

University of Nebraska-Lincoln, kpope2@unl.edu

Follow this and additional works at: https://digitalcommons.unl.edu/ncfwrustaff

Kowalewski, Lucas K.; Maple, Alexis P.; Pegg, Mark A.; and Pope, Kevin L., "Latitudinal Influence on Age Estimates Derived from Scales and Otoliths for Bluegills" (2012). Nebraska Cooperative Fish \& Wildlife Research Unit -- Staff Publications. 105.

https://digitalcommons.unl.edu/ncfwrustaff/105

This Article is brought to you for free and open access by the Nebraska Cooperative Fish \& Wildlife Research Unit at DigitalCommons@University of Nebraska - Lincoln. It has been accepted for inclusion in Nebraska Cooperative Fish \& Wildlife Research Unit -- Staff Publications by an authorized administrator of DigitalCommons@University of Nebraska - Lincoln. 


\title{
Latitudinal Influence on Age Estimates Derived from Scales and Otoliths for Bluegills
}

\author{
Lucas K. Kowalewski* and Alexis P. Maple ${ }^{1}$ \\ Nebraska Cooperative Fish and Wildlife Research Unit, School of Natural Resources, \\ University of Nebraska, 013 Hardin Hall, Lincoln, Nebraska 68583, USA
}

Mark A. Pegg

School of Natural Resources, University of Nebraska, 402 Hardin Hall, Lincoln, Nebraska 68583, USA

Kevin L. Pope

U. S. Geological Survey-Nebraska Cooperative Fish and Wildlife Research Unit,

School of Natural Resources, University of Nebraska, 424 Hardin Hall, Lincoln, Nebraska 68583, USA

\begin{abstract}
Scales are perceived to give reliable estimates of age of fish in northern latitudes and unreliable estimates of age in southern latitudes, whereas otoliths are perceived to give reliable estimates of age regardless of latitude. The objective of our study was to assess the influence of latitude on the estimates of ages derived from scales and otoliths for bluegill Lepomis macrochirus. Our hypothesis was that a south-to-north gradient exists for precision between scales and otoliths with partial agreement between age estimates derived from scales and otoliths for fish in southern latitudes and nearly complete agreement between age estimates derived from scales and otoliths for fish in northern latitudes. Fish were sampled from Louisiana (latitude $=\mathbf{3 0}^{\circ} \mathbf{4 3}^{\prime} \mathbf{4 8}^{\prime \prime} \mathrm{N}$ ) to North Dakota (latitude $\left.=47^{\circ} 05^{\prime} 49^{\prime \prime} \mathrm{N}\right)$. Contrary to a priori expectations, we did not find greater agreement in age estimates between structures in northern bluegill stocks than in those in the southern USA. The low agreement between structures increases uncertainty in the source of aging error, given that both scales and otoliths are valid structures (i.e., age estimates validated as accurate) for estimating ages of bluegills. Biologists should not compare age-dependent parameters for bluegill populations derived from different aging structures.
\end{abstract}

Scales and otoliths, two calcified structures in which annual marks (i.e., annuli) are formed, are widely used for estimating the age of fish (DeVries and Frie 1996; Campana and Thorrold 2001). Annuli are formed in calcified structures during periods of slow growth, generally associated with cold weather in temperate climates (DeVries and Frie 1996). Age estimates derived from scales have been validated for bluegill Lepomis macrochirus using known-age fish in New York (Regier 1962), and age estimates derived from otoliths have been validated for bluegills using marginal-increment analysis in South Carolina (Hales and Belk 1992). Lucchesi and Johnson (2006) compared the amount of time for removal and processing of scales and otoliths to estimate ages for walleye Sander vitreus and yellow perch Perca flavescens; they reported a similar amount of time to read and process each structure. Collection of scales is frequently preferred to collection of otoliths because fish from which only scales have been taken can be released alive.

Accurate age estimates are vital for quantifying population dynamics (e.g., recruitment, growth, and mortality) and assessing age structure of a population. Furthermore, a recent emphasis has been placed on standardization of methods to compare data gathered across large geographic areas (Bonar and Hubert 2002; Bonar et al. 2009). Inaccuracy in age estimation of fishes is caused by error associated with interpretation of annuli (Campana 2001), which is compounded by variability in the quality of annuli. Quality of annuli can differ among populations and years due to environmental factors that influence physiological mechanisms controlling formation of annuli; quality can also differ between the calcified structures being examined. Not all calcified structures in fish form a complete growth sequence throughout the lifetime of the animal (Casselman 1990). Therefore, aging techniques that produce accurate estimates are essential for analysis of population dynamics (Summerfelt and Hall 1987; Campana 2001).

*Corresponding author: lkowalewski2@unl.edu

${ }^{1}$ Present address: Maryland Department of Natural Resources, 301 Marine Academy Drive, Stevensville, Maryland 21666, USA.

Received June 29, 2012; accepted July 24, 2012 
Quantification of the accuracy of age estimates is typically determined when estimating age of known-age fish or through marginal-increment analysis-information that typically is not available when sampling wild populations. In contrast, quantification of the precision of age estimates derived from two different calcified structures from the same fish (e.g., scales and otoliths) can be easily obtained. Although an estimate of precision and associated error does not provide an estimate of the true value of the quantity being measured, it does provide a distribution from which the probability of the existence of an independent random variable can be determined. Given that both age estimation methods we evaluated have been validated, we considered precision of estimates between structures as a measure of uncertainty that is introduced in age estimation.

Latitude of origin has a potential impact on the precision of age estimates of fish. The lack of a definitive cold season in southern latitudes affects physiological mechanisms that control annuli formation. In contrast, fish populations from northern latitudes typically experience definitive periods of fast growth associated with warm temperatures and slow growth associated with cool temperatures. Decreased precision between age estimates derived from scales and otoliths has been documented in fish from southern latitudes (Schramm and Doerzbacher 1985; Boxrucker 1986; Hammers and Miranda 1991). The loss of precision in age estimates between structures has been attributed to a reader's inability to distinguish annuli formation on scales because of the effects of climate on the seasonal growth and metabolic activity of fish (Schramm and Doerzbacher 1985; Boxrucker 1986; Hoxmeier et al. 2001). Thus, fish from southern latitudes, with shorter or intermittent cold seasons, may have indistinguishable annuli on scales. In contrast, otoliths have been used to accurately age fish from both southern and northern latitudes (Schramm and Doerzbacher 1985; Boxrucker 1986; Kruse et al. 1993; Hoxmeier et al. 2001). A reader's ability to accurately estimate age with scales and otoliths has been studied at relatively small spatial ranges (Boxrucker 1986; Hammers and Miranda 1991; Kruse et al. 1993; Hoxmeier et al. 2001; Edwards et al. 2005) but has not been thoroughly evaluated across a large latitudinal gradient. Therefore, we evaluated the influence of latitude $\left(30^{\circ} 43^{\prime} 48^{\prime \prime} \mathrm{N}\right.$ through $\left.47^{\circ} 05^{\prime} 49^{\prime \prime} \mathrm{N}\right)$ on the precision of age estimates derived from scales and otoliths for bluegills. Our hypothesis was that a south-to-north gradient exists for precision between scales and otoliths, that is, partial agreement between age estimates derived from scales and from otoliths for fish in southern latitudes and nearly complete agreement between age estimates derived from scales and otoliths for fish in northern latitudes. If correct, then a latitudinal threshold should exist for interchangeable utility between scales and otoliths for age estimation.

\section{METHODS}

Collection of bluegills. - We analyzed scales and otoliths of bluegills from populations centered along a line (longitude $=$ $93^{\circ} 42^{\prime} 48^{\prime \prime} \mathrm{W}$ to $97^{\circ} 07^{\prime} 09^{\prime \prime} \mathrm{W}$ ) from the Texas-Louisiana border north to the North Dakota-Minnesota border (latitudes = $30^{\circ} 43^{\prime} 48^{\prime \prime} \mathrm{N}$ through $47^{\circ} 05^{\prime} 49^{\prime \prime} \mathrm{N}$ ). Bluegill samples were provided by biologists representing state agencies along the latitudinal gradient. Each biologist was asked to collect bluegills from all age groups present during sampling and to weight the sampling toward older age groups because we assumed discrepancies in age estimates would be more prevalent in older fish. Fish were frozen and shipped to University of NebraskaLincoln Fishery Science Laboratory for processing. In the laboratory, each fish was thawed and individually numbered. Scales (collected from under the tip of the pectoral fin when pressed against the body) and otoliths were removed for age analyses following procedures described by DeVries and Frie (1996).

Structure aging.-Scales were pressed onto acetate slides and viewed through a microfiche reader. Scale annuli were identified by close spacing of the circuli and cross-over points (Jerald 1983; Kruse et al. 1993). Whole otoliths were submerged in a black petri dish filled with water and viewed through a dissecting microscope with reflected light. Otolith annuli were identified as lighter colored, opaque bands (representing reduced growth increments) separated by darker colored, translucent bands (representing increased growth increments). All scales and otoliths were read separately by two independent readers to estimate fish age. To reduce reader bias, we resolved all discrepancies in age estimates between readers with a concert read (Campana 2001; Buckmeier et al. 2002). Age bias plots with linear regression were constructed for each population to examine the precision of age estimates derived from scales and otoliths (Phelps et al. 2007). Analysis of variance (ANOVA) was used to determine whether the slope of the regression line differed from 1 , and in cases in which it did not differ from 1 , to determine whether the $y$-intercept differed from 0 . We estimated growth parameters (asymptotic average length $\left[L_{\infty}\right]$ and growth rate coefficient $[K]$ ) and instantaneous mortality (Z) using our study fish to illustrate potential influences of discrepancies in age estimates; we caution readers that the bluegill samples provided for this study were not representative of actual populations because we requested samples weighted toward older (i.e., larger) fish.

\section{RESULTS AND DISCUSSION}

We expected to find significant differences between regression lines and the 1:1 line in southern populations and no differences in northern populations. Contrary to a priori expectations, however, we found no evidence of a latitudinal gradient in any agreement of age estimates derived from scales and otoliths of bluegill. Age estimates derived from scales and otoliths were significantly different in 14 of 15 populations assessed (Figure 1). We found five populations in which the slope of the regression line did not differ from 1, but only one population in which slope did not differ from 1 and the $y$-intercept 


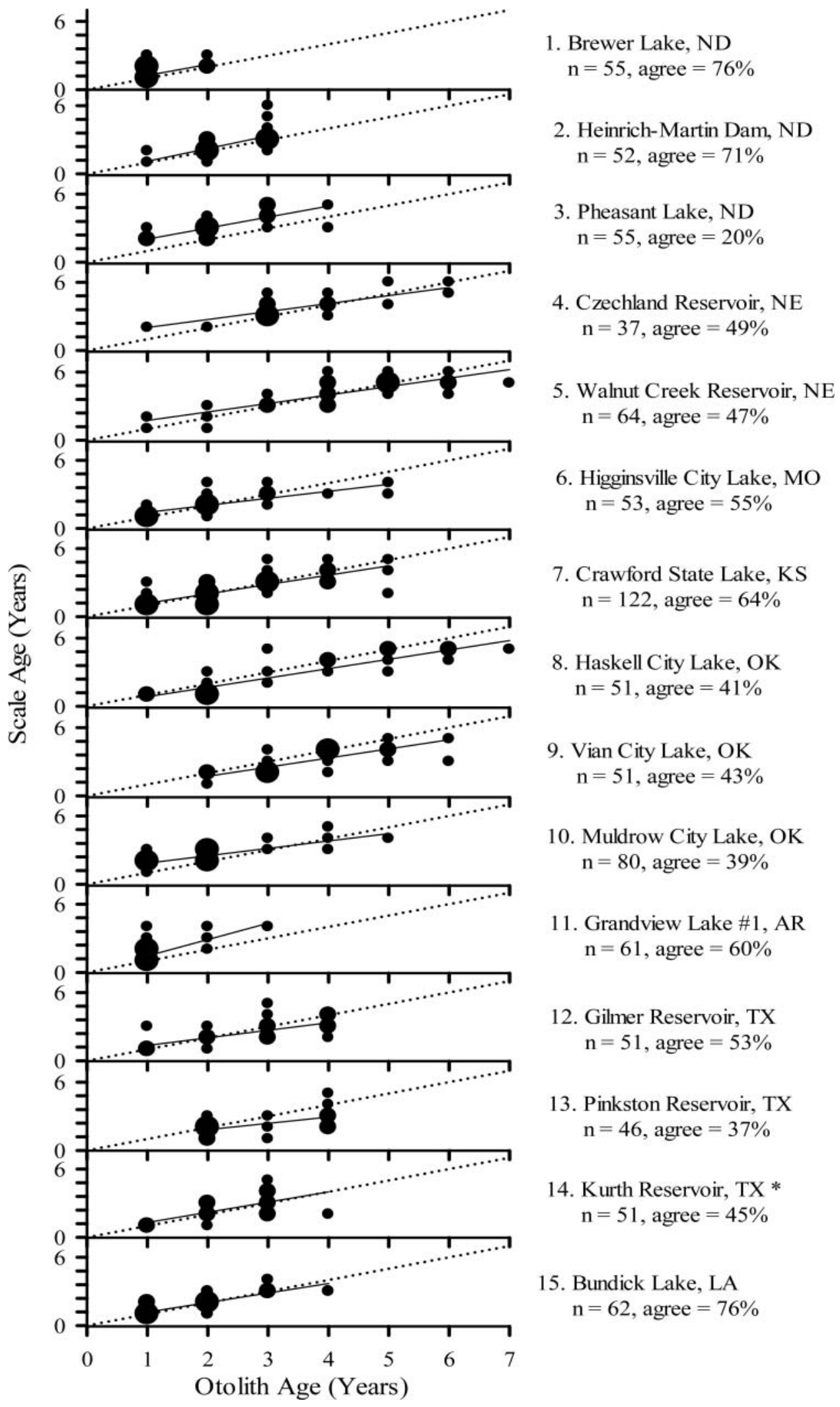

FIGURE 1. Age bias plots for 15 bluegill populations. Linear regression indicated by solid black line. All regressions were significant $(P<0.001)$. The $1: 1$ dotted line (age estimates derived from scales = age estimates derived from otoliths) is provided for reference. The number of bluegills represented by each data point is indicated by size of data point: 1-4 bluegills for small points, 5-9 bluegills for medium points, and 10 or more bluegills for large points. Asterisk denotes regression slope $=1$, and $y$-intercept $=0$. Sample size $(n)$ and structure agreement (agree; \%) are provided for each population. 


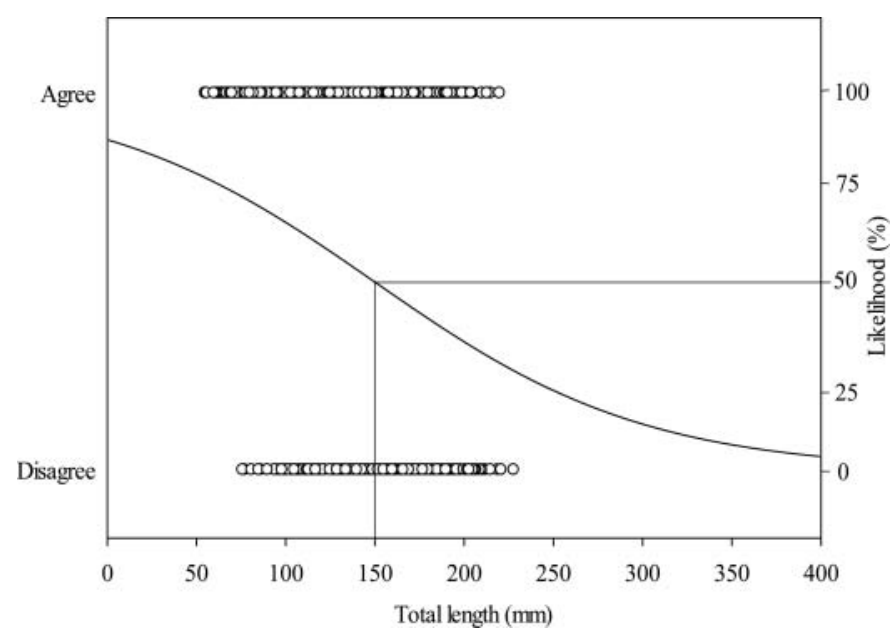

FIGURE 2. Logistic regression of agreement of age estimates derived from scales and from otoliths plotted as a function of total length $(\mathrm{mm})$ for bluegills $(n=891)$. A $50 \%$ likelihood of agreement occurred at a total length of $150 \mathrm{~mm}$.

did not differ from 0 . A logistic regression of agreement of age estimates derived from scales and otoliths plotted as a function of total length $(\mathrm{mm})$ for sampled bluegills indicated a likelihood of agreement of $50 \%$ at a total length of $150 \mathrm{~mm}$ (Figure 2). Apparently, the disagreement between aging structures of bluegills is prevalent for large $(\geq 150 \mathrm{~mm})$ bluegill throughout the latitudinal range that we assessed. This low agreement between age estimates derived from scales and from otoliths across the latitudinal gradient examined was unexpected, given that both scales and otoliths are considered valid structures (i.e., age estimates are validated as accurate) for estimating ages of bluegills.

The low agreement increases uncertainty in the source of aging error, which creates difficulty for biologists when comparing bluegill population dynamics that had been generated from age data estimated with a combination of scales and otoliths. Relative use of scales to age sunfish increased with latitude (Maceina et al. 2007); accordingly, use of scales to age sunfish is limited for state agencies located south of the 40th parallel (KansasNebraska border; Maceina et al. 2007). Given our hypothesis, we anticipated that age estimates derived from scales and from otoliths should not be used interchangeably in the southern portion of the latitudinal gradient examined, but our data suggest this issue exists across the entire geographic range. Our results suggest that conclusions drawn from age-based assessments obtained using these two structures (Table 1) could result in different, possibly conflicting, management recommendations. Thus, biologists should not compare age-based assessments of bluegill populations when the age estimates were derived from a combination of both kinds of aging structures. Furthermore, we recommend that validation studies for age estimates of both scales and otoliths be completed across a wide range of latitudes for bluegills of at least $150 \mathrm{~mm}$ total length to better understand error in precision between structures.

TABLE 1. Comparison of asymptotic average length $\left(L_{\infty}\right)$ and growth rate coefficient $(K)$ from the Von Bertalanffy growth equation and instantaneous mortality rate $(Z)$ between models by using ages derived from scales and from otoliths for each bluegill population. Percent difference was calculated for parameter estimates according to the formula $\left(\left(\left|\left(X_{\text {scale }}-X_{\text {otolith }}\right)\right| /\left(0.5\left(X_{\text {scale }}+X_{\text {otolith }}\right)\right) * 100\right)\right.$.

\begin{tabular}{|c|c|c|c|c|c|c|c|c|c|}
\hline \multirow[b]{3}{*}{ Reservoir } & \multicolumn{3}{|c|}{$L_{\infty}(\mathrm{mm})$} & \multicolumn{3}{|c|}{$K$} & \multicolumn{3}{|c|}{$Z$} \\
\hline & \multicolumn{2}{|c|}{ Age derived from } & \multirow[b]{2}{*}{$\%$ Diff. } & \multicolumn{2}{|c|}{ Age derived from } & \multirow[b]{2}{*}{ \% Diff. } & \multicolumn{2}{|c|}{ Age derived from } & \multirow[b]{2}{*}{ \% Diff. } \\
\hline & Scales & Otoliths & & Scales & Otoliths & & Scales & Otoliths & \\
\hline Brewer Lake, ND & * & * & * & * & * & * & 1.228 & 1.631 & 28 \\
\hline Heinrich Martin Dam, ND & 238 & * & * & 0.359 & * & * & 0.880 & $-0.214^{\mathrm{a}}$ & 329 \\
\hline Pheasant Lake, ND & 270 & * & * & 0.173 & * & * & 0.257 & 1.134 & 126 \\
\hline Czechland Reservoir, NE & 211 & 228 & 8 & 0.540 & 0.317 & 52 & 0.607 & 0.775 & 24 \\
\hline Walnut Creek Reservoir, NE & 200 & 194 & 3 & 0.471 & 0.534 & 13 & 0.092 & 0.409 & 127 \\
\hline Higginsville City Lake, MO & 168 & 156 & 7 & 0.437 & 0.633 & 37 & 0.232 & 0.374 & 47 \\
\hline Crawford State Lake, KS & 191 & 196 & 3 & 0.725 & 0.725 & 0 & 0.572 & 0.548 & 4 \\
\hline Haskell City Lake, OK & 241 & 260 & 8 & 0.370 & 0.281 & 27 & $-0.040^{\mathrm{a}}$ & 0.358 & 250 \\
\hline Vian City Lake, OK & 225 & 280 & 22 & 0.373 & 0.190 & 65 & 0.914 & 0.304 & 100 \\
\hline Muldrow City Lake, OK & 298 & 188 & 45 & 0.142 & 0.576 & 121 & 1.017 & 0.631 & 47 \\
\hline Grandview Lake \#1, AR & 218 & 178 & 20 & 0.275 & 2.092 & 154 & 0.798 & 1.994 & 86 \\
\hline Gilmer Reservoir, TX & 196 & 226 & 14 & 0.785 & 0.435 & 57 & 0.919 & $-0.187^{\mathrm{a}}$ & 302 \\
\hline Pinkston Reservoir, TX & 154 & 155 & 1 & 0.821 & 1.000 & 20 & 0.914 & $-0.027^{\mathrm{a}}$ & 212 \\
\hline Kurth Reservoir, TX & 171 & 231 & 30 & 1.259 & 0.399 & 104 & 0.588 & 0.420 & 33 \\
\hline Bundick Lake, LA & 574 & 344 & 50 & 0.077 & 0.156 & 68 & 0.664 & 0.795 & 18 \\
\hline
\end{tabular}

${ }^{a}$ We recognize $Z$ cannot be negative; values are reported only for comparison purposes, to illustrate differences in estimates. 


\section{ACKNOWLEDGMENTS}

We thank the following biologists and agencies for providing fish: Bobby Reed, Louisiana Department of Wildlife and Fisheries; Tim Bister, Texas Parks and Wildlife Department; Gary Peterson, Oklahoma Department of Wildlife Conservation; Les Claybrook, Arkansas Game and Fish Commission; Rob Friggeri, Kansas Department of Wildlife and Parks; Rich Meade, Missouri Department of Conservation; Jeff Jackson, Nebraska Game and Parks Commission; and Gene Van Eeckhout, North Dakota Game and Fish Department. This project was partially funded by the Undergraduate Creative Activities and Research Experiences (UCARE) Program, supported by the Office of Undergraduate Studies and by the Pepsi Endowment and Program of Excellence funds. We thank Andrew Furman (UCARE student) for processing bluegills and Tony Barada and Dustin Martin for guidance and help during writing of this manuscript. The use of trade names or products does not constitute endorsement by the U.S. Government. The Nebraska Cooperative Fish and Wildlife Research Unit is jointly supported by a cooperative agreement between the U.S. Geological Survey, the Nebraska Game and Parks Commission, the University of Nebraska, the U.S. Fish and Wildlife Service, and the Wildlife Management Institute.

\section{REFERENCES}

Bonar, S. A., and W. A. Hubert. 2002. Standard sampling of inland fish: benefits, challenges, and a call for action. Fisheries 27(3):10-16.

Bonar, S. A., S. Contreras-Balderas, and A. C. Iles. 2009. An introduction to standardized sampling. Pages 1-12 in S. A.Bonar, W. A.Hubert, and D. W.Willis, editors. Standard methods for sampling North American freshwater fishes. American Fisheries Society, Bethesda, Maryland.

Boxrucker, J. 1986. A comparison of the otolith and scale methods for aging white crappies in Oklahoma. North American Journal of Fisheries Management 6:122-125.

Buckmeier, D. L., E. R. Irwin, R. K. Betsill, and J. A. Prentice. 2002. Validity of otoliths and pectoral spines for estimating ages of channel catfish. North American Journal of Fisheries Management 22:934-942.

Campana, S. E. 2001. Accuracy, precision and quality control in age determination, including a review of the use and abuse of age validation methods. Journal of Fish Biology 59:197-242.
Campana, S. E., and S. R. Thorrold. 2001. Otoliths, increments and elements: keys to a comprehensive understanding of fish populations? Canadian Journal of Fisheries and Aquatic Sciences 58:30-38.

Casselman, J. M. 1990. Growth and relative size of calcified structures of fish. Transactions of the American Fisheries Society 119:673-688.

DeVries, D. R., and R. V. Frie. 1996. Determination of age and growth. Pages 483-512 in B. R. Murphy and D. W. Willis, editors. Fisheries techniques, 2nd edition. American Fisheries Society, Bethesda, Maryland.

Edwards, K. R., Q. E. Phelps, J. L. Shepherd, D. W. Willis, and J. D. Jungwirth. 2005. Comparison of scale and otolith age estimates for two South Dakota bluegill populations. Proceedings of the South Dakota Academy of Science 84:181-186.

Hales, L. S. Jr., and M. C. Belk. 1992. Validation of otolith annuli of bluegills in a southeastern thermal reservoir. Transactions of the American Fisheries Society 121:823-830.

Hammers, B. E., and L. E. Miranda. 1991. Comparison of methods for estimating age, growth, and related population characteristics of white crappies. North American Journal of Fisheries Management 11:492-498.

Hoxmeier, R. J. H., D. D. Aday, and D. H. Wahl. 2001. Factors influencing precision of age estimation from scales and otoliths of bluegills in Illinois reservoirs. North American Journal of Fisheries Management 21:374-380.

Jerald, A. Jr. 1983. Age determination. Pages 301-324 in L. A. Nielsen and D. L. Johnson, editors. Fisheries techniques. American Fisheries Society, Bethesda, Maryland.

Kruse, C. G., C. S. Guy, and D. W. Willis. 1993. Comparison of otolith and scale characteristics for black crappies collected from South Dakota waters. North American Journal of Fisheries Management 13:856-858.

Lucchesi, D. O., and B. Johnson. 2006. Evaluation of scales and otoliths for walleye and yellow perch age estimation. South Dakota Department of Game, Fish, and Parks, Progress Report 06-21, Pierre.

Maceina, M. J., J. Boxrucker, D. L. Buckmeier, R. S. Gangl, D. O. Lucchesi, D. A. Isermann, J. R. Jackson, and P. J. Martinez. 2007. Current status and review of freshwater fish aging procedures used by state and provincial fisheries agencies with recommendations for future directions. Fisheries 32:329339.

Phelps, Q. E., K. R. Edwards, and D. W. Willis. 2007. Precision of five structures for estimating age of common carp. North American Journal of Fisheries Management 27:103-105.

Regier, H. A. 1962. Validation of the scale method for estimating age and growth of bluegills. Transactions of the American Fisheries Society 91:362-374.

Schramm, H. L. Jr., and J. F. Doerzbacher. 1985. Use of otoliths to age black crappie from Florida. Proceedings of the Annual Conference Southeastern Association of Fish and Wildlife Agencies 36(1982):95-105.

Summerfelt, R. C., and G. E. Hall. 1987. Age and growth of fish. Iowa State University Press, Ames. 